\title{
Numerical Simulation of Phosphorus Removal from Silicon by Induction Vacuum Refining
}

\author{
SONGSHENG ZHENG, THORVALD ABEL ENGH, MERETE TANGSTAD, \\ and XUE-TAO LUO
}

\begin{abstract}
Phosphorus can be expected to evaporate preferentially from silicon melt by induction vacuum refining (IVR). In the present study, on the assumption of phosphorus evaporating from silicon melt as gas species $P$ and $P_{2}$, a numerical model of phosphorus removal from silicon by IVR was developed. The factors affecting phosphorus removal in decreasing order are temperature, chamber pressure, geometry of silicon melt, holding time, and original phosphorus concentration. Calculated phosphorus removal shows good agreement with the present experimental data.
\end{abstract}

DOI: $10.1007 / \mathrm{s} 11661-011-0621-3$

(C) The Author(s) 2011. This article is published with open access at Springerlink.com

\section{INTRODUCTION}

PHOSPHORUS is an impurity in silicon difficult to remove. For solar cell applications, there are limitations on the level of impurities as in semiconductor-grade silicon, but the acceptable levels are substantially higher. The maximum permissible concentrations of individual impurities in solar-grade silicon are defined by studying the conversion efficiency of solar cells as a function of impurity concentration. As is shown in Figure 1, the limits on impurity concentrations in $p$-type silicon for solar cells are reported by Bathey et al., ${ }^{[1]}$ Gribov et al., ${ }^{[2]}$ and Dietl. ${ }^{[3]}$ The required maximum limit for phosphorus content in solar grade silicon should be less than 0.1 ppma.

Vacuum refining is one of the conventional processes in metallurgy, and phosphorus can be expected to evaporate preferentially from silicon melt under vacuum refining with its higher vapor pressure than silicon. Experiments to remove phosphorus under vacuum conditions were investigated by Zheng et al., ${ }^{[4]}$ Miyake et al., ${ }^{[5]}$ Yuge et al., ${ }^{[6]}$ Suzuki et al., ${ }^{[7]}$ Pires et al.., ${ }^{[8]}$ and Ikeda and Maeda, ${ }^{[9]}$ and the thermodynamics of phosphorus in molten silicon was also presented by Miki et al. ${ }^{[10]}$ and Zaitsev et al. ${ }^{[11]}$ In the present study, a numerical model for phosphorus removal in vacuum induction refining of silicon is developed and compared to experimental data.

\section{THERMODYNAMIC EQUILIBRIUM}

Understanding of the thermodynamics and kinetics of evaporation of volatile impurities from a liquid metal bath held under vacuum requires information on the vapor pressure of constituent gas species above the melt.

SONGSHENG ZHENG, Postdoctoral candidate, and XUE-TAO LUO, Professor, are with the Department of Materials Science and Engineering, Xiamen University, Xiamen 361005, People's Republic of China. Contact e-mail: xuetao@xmu.edu.cn THORVALD ABEL ENGH and MERETE TANGSTAD, Professors, are with the Department of Material Science and Engineering, Norwegian University of Science and Technology, Trondheim 7034, Norway.

Manuscript submitted July 15, 2010.

Article published online February 15, 2011
The equilibrium partial pressure of silicon is

$$
p_{\mathrm{Si}}^{e}=p_{\mathrm{Si}}^{0} \gamma_{\mathrm{Si}} x_{\mathrm{Si}}
$$

where $p_{\mathrm{Si}}^{0}$ is the vapor pressure of pure silicon; $\gamma_{\mathrm{Si}}$ is the Raoultian activity coefficient of silicon, taken as unity here; and $x_{\mathrm{Si}}$ is the molar fraction of silicon. The vapor pressure is calculated by the Van Laar equation: ${ }^{[12,13]}$

$$
\log p_{\mathrm{Si}}^{o}=-20,900 T^{-1}-0.565 \log T+12.9
$$

The partial pressure of phosphorus vapor above liquid silicon is complex since phosphorus has three significant gaseous species. As is reported by Schlesinger, ${ }^{[14]}$ vaporizing red or liquid phosphorus forms a gas consisting primarily of $P_{4}$, which is the predominant form below $973 \mathrm{~K}\left(700^{\circ} \mathrm{C}\right)$. Above this temperature, the presence of $P_{2}$ vapor becomes noticeable and increasingly dominant above $1533 \mathrm{~K}\left(1260^{\circ} \mathrm{C}\right)$. At much higher temperatures, monatomic phosphorus vapor begins to appear. Therefore, the partial pressure of phosphorus vapor above liquid silicon is decided by the thermodynamic properties of $p_{P}, p_{P_{2}}$, and $p_{P_{4}}$.

According to the investigation of Miki et al. ${ }^{[10]}$ phosphorus evaporated from Si-P alloy mainly contains $P$ and $P_{2}$ gas species. The present work, in developing a model for phosphorus evaporation from molten silicon, assumes that phosphorus vapor above liquid silicon consists of only $P$ and $P_{2}$ gas species. The Gibbs energy change of $P$ and $P_{2}$ gas species and their equilibrium partial pressure calculated from the Gibbs energy change are listed in Table I.

In Table I, $K$ is the equilibrium constant, $p_{\text {atm }}$ is atmospheric pressure $(101,325 \mathrm{~Pa})$, and $f_{P}$ is the activity coefficient of phosphorus relative to $1 \mathrm{wt}$ pet in liquid silicon. According to Wagner, ${ }^{[15]}$ the activity coefficient of solutes in a solution can be expressed as

$$
\ln f_{\mathrm{i}}=\sum_{\mathrm{j}=2}^{n} \ln f_{\mathrm{i}}^{\mathrm{j}}=\sum_{j=2}^{n} \varepsilon_{\mathrm{i}}^{\mathrm{j}} \cdot x_{\mathrm{j}}
$$

Here, $\varepsilon_{1}^{j}$ is the activity interaction coefficient. When taking no account of the effects of other impurities, we have 
Table I. Thermodynamic of $\boldsymbol{P}$ and $\boldsymbol{P}_{2}$ Gas Species above Silicon Melt

$P($ wt pct $P$, in Si $)=\frac{1}{2} P_{2}(\mathrm{~g})$
$\Delta G_{1}^{\mathrm{o}}=139000( \pm 2000)-43.4( \pm 10.1) T(\mathrm{~J} / \mathrm{mol})^{[9]}$
$\Delta G_{1}^{\mathrm{o}}=-R T \ln K=-R T \ln \left\{\left(p_{P_{2}}^{e} / p_{\mathrm{atm}}\right)^{1 / 2} / f_{P} \cdot[\right.$ wt pct $\left.P]\right\}$
$p_{P_{2}}^{e}=p_{\mathrm{atm}} \cdot\left\{f_{P} \cdot[\text { wt pct } \cdot P] \cdot \exp \left(-\Delta G_{1}^{o} / R T\right)\right\}^{2} \quad(\mathrm{~Pa})$
$P($ wt pct $P$, in Si $)=P(\mathrm{~g})$
$\Delta G_{2}^{\mathrm{o}}=387000( \pm 2000)-142( \pm 10) T(\mathrm{~J} / \mathrm{mol})^{[10]}$
$\Delta G_{2}^{\mathrm{o}}=-R T \ln K=-R T \ln \left\{\left(p_{P}^{e} / p_{\mathrm{atm}}\right) / f_{P} \cdot[\mathrm{wt}\right.$ pct $\left.P]\right\}$
$p_{P}^{e}=p_{\mathrm{atm}} \cdot f_{P} \cdot[$ wt pct $P] \cdot \exp \left(-\Delta G_{2}^{\mathrm{o}} / R T\right) \quad(\mathrm{Pa})$

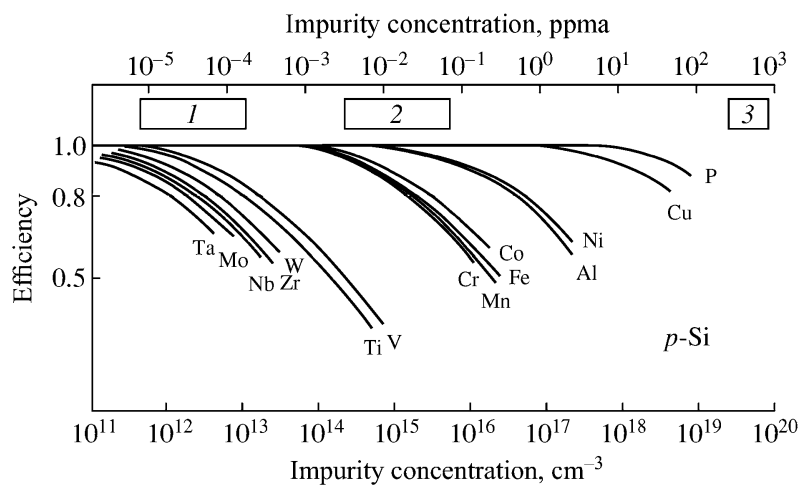

Fig. 1-Limits on impurity concentrations in $p$-type silicon for impurities determining the degradation threshold of solar cells: (1) semiconductor-, (2) solar-, and (3) metallurgical-grade silicon. ${ }^{[1,2]}$.

$$
\ln f_{P}=\frac{\varepsilon_{P \text { in Si }}^{P} \cdot M_{\mathrm{Si}}}{100 M_{P}} \cdot[\text { wt pct } P]
$$

where $^{[16]}$

$$
\varepsilon_{P \text { in Si }}^{P}=13.8( \pm 3.2)
$$

The equilibrium partial pressure of $P$ and $P_{2}$, as a function of phosphorus concentration in silicon at a given temperature can be calculated, as shown in Figure 2 at a temperature of $1823 \mathrm{~K}\left(1550{ }^{\circ} \mathrm{C}\right)$.

The calculation shows that, at low phosphorus concentrations below 0.005 [wt pet $P$ ], monatomic phosphorus vapor is dominant in the gas phase at temperature $1823 \mathrm{~K}\left(1550{ }^{\circ} \mathrm{C}\right)$, as is also stated by Miki et al. ${ }^{[10]}$

\section{MODEL DESCRIPTION}

The present model is developed for phosphorus evaporation from silicon melt by induction vacuum refining (IVR). As is shown in Figure 3, the transfer path of phosphorus during silicon refining includes five steps:

(1) transport of an atom through the melt to the neighborhood of the melt surface,

(2) transport across a liquid boundary layer to the melt surface,

(3) vaporization from the free melt surface into the gas phase above the surface,

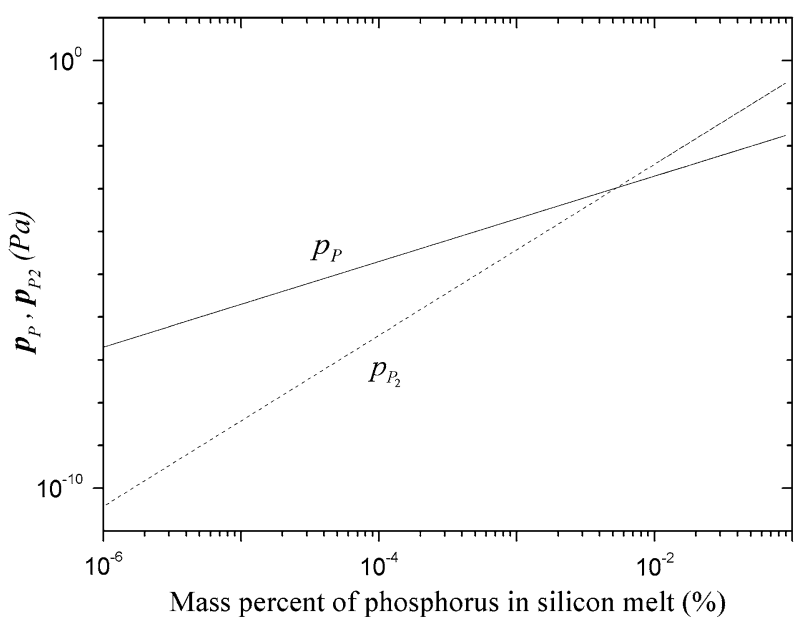

Fig. 2-Equilibrium partial pressure of $P$ and $P_{2}$ species as a function of phosphorus concentration in silicon at $1823 \mathrm{~K}\left(1550{ }^{\circ} \mathrm{C}\right)$.

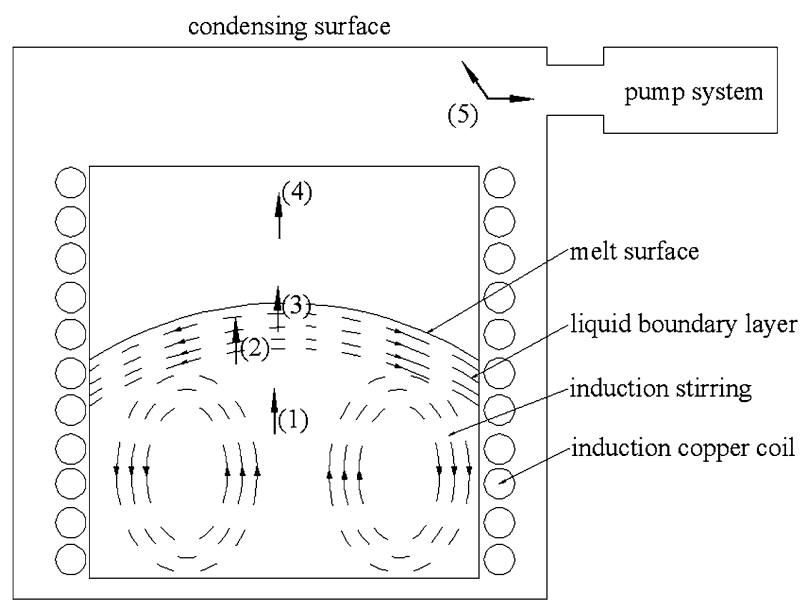

Fig. 3-Schematic of IVR model describing the transfer path of phosphorus during silicon refining.

(4) transport across a gas phase in the chamber, and

(5) condensation on the chamber inner surface or gas removal by pump.

The IVR model simplifications are as follows: (1) the silicon is assumed to have only phosphorus as an impurity element, (2) inductive stirring gives rapid movement in the melt, (3) a liquid phase boundary layer near the surface of the melt is considered to be rigid flow moving without shear gradients under the influence of inductive stirring, and (4) the gas boundary layer will not be discussed separately but included in step 3 as a factor of vaporization driving force.

The gas-liquid interface of silicon melt is shown in Figure 4. The phosphorus evaporation is accompanied by silicon vaporization. Therefore, the evaporation kinetics of both silicon and phosphorus will be discussed.

\section{A. Kinetics of Si Evaporation}

During the evaporation of phosphorus from molten silicon, silicon will vaporize as well. Since the concentration 


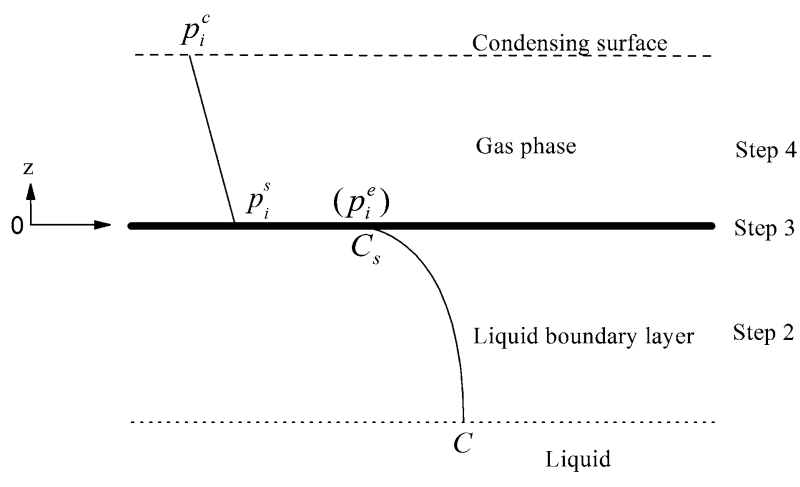

Note: Here $i$ can be gas species $P, P_{2}$ or $S i$ vapor

Fig. 4-Sketch of gas-liquid interface of silicon melt.

of phosphorus in silicon is very low and silicon behaves as pure liquid, we can consider free surface evaporation (step 3 ) and diffusion through the gas phase (step 4) as two possible rate limiting steps for silicon vaporization.

In step 3, free evaporation of silicon should observe the Hertz-Langmuir-Knudsen equation. When a perfect vacuum above the silicon melt is not attained, the flux of silicon is given by ${ }^{[17-19]}$

$$
j_{\mathrm{Si}, \mathrm{St} .3}=\frac{\alpha A\left(p_{\mathrm{Si}}^{e}-p_{\mathrm{Si}}^{s}\right)}{\sqrt{2 \pi R T M_{\mathrm{Si}}}}(\text { moles } / \mathrm{s})
$$

Step 4, the flux of silicon in the gas phase, should include the diffusion flux and the convective flux: ${ }^{[20]}$

$$
j_{\mathrm{Si}, \mathrm{St} .4}=-\frac{A D_{\mathrm{Si}(\mathrm{g})}}{R T} \frac{d p_{\mathrm{Si}}}{d z}+\frac{p_{\mathrm{Si}}}{p_{\mathrm{tot}}}\left(j_{P, \mathrm{St} .4}+j_{P_{2}, \mathrm{St} .4}+j_{\mathrm{Si}, \mathrm{St} .4}+j_{\mathrm{res}}\right)
$$

In which $j_{P, \mathrm{St} .4}, j_{P 2}, \mathrm{St} .4, j_{\mathrm{Si}, \mathrm{St} .4}$, and $j_{\text {res }}$ is the gas-phase flux of gas species $P$ and $P_{2}, \mathrm{Si}$, and residual gas, respectively. $D_{\mathrm{Si}(g)}$ is the molecular diffusion coefficient of silicon in the gas phase. $p_{\mathrm{Si}}$ and $p_{\text {tot }}$ are the partial pressures of silicon vapor along the normal to the surface and the total pressure in the chamber, respectively. Silicon vapor is the main component during the evaporation so the fluxes of the other components in the chamber are negligible. Then, by integrating Eq. [9], the flux of silicon in the gas phase is

$$
j_{\mathrm{Si}, \mathrm{St} .4}=\frac{A D_{\mathrm{Si}(\mathrm{g})} p_{\mathrm{tot}}}{R T \delta} \cdot \ln \left(\frac{p_{\mathrm{tot}}-p_{\mathrm{Si}}^{c}}{p_{\mathrm{tot}}-p_{\mathrm{Si}}^{s}}\right)(\text { moles } / \mathrm{s})
$$

where $p_{\mathrm{Si}}^{s}$ is the partial pressure of silicon vapor at the melt surface, $p_{\mathrm{Si}}^{c}$ is the partial pressure of silicon on the condensation surface and is taken as zero, and $\delta$ is the distance from the melt surface to the condensation surface without considering the gas-boundary layer:

$$
j_{\mathrm{Si}, \mathrm{St} .4}=-\frac{A D_{\mathrm{Si}(\mathrm{g})}}{R T \delta} \cdot \frac{\ln \left(1-x_{\mathrm{Si}}^{s}\right)}{x_{\mathrm{Si}}^{s}} \cdot p_{\mathrm{Si}}^{s}(\text { moles } / \mathrm{s})
$$

Here,

$$
x_{\mathrm{Si}}^{s}=\frac{p_{\mathrm{Si}}^{s}}{p_{\mathrm{tot}}}
$$

According to the quasi-steady-state approximation, $j_{\mathrm{Si}, \mathrm{St} .3}=j_{\mathrm{Si}, \mathrm{St} .4}=j_{\mathrm{Si}}$, combining Eqs. [8] and [11], we eliminate $p_{\mathrm{Si}}^{s}$. The total mass transfer coefficient $k_{\mathrm{Si}}$ is defined by

$$
j_{\mathrm{Si}}=A \frac{k_{\mathrm{Si}}}{R T} p_{\mathrm{Si}}^{e}(\text { moles } / \mathrm{s})
$$

Here, $k_{\mathrm{Si}}$ is given by

$$
\frac{1}{k_{\mathrm{Si}}}=\frac{1}{\alpha} \sqrt{\frac{2 \pi M_{\mathrm{Si}}}{R T}}-\frac{\delta}{D_{\mathrm{Si}(\mathrm{g})}} \cdot \frac{x_{\mathrm{Si}}^{s}}{\ln \left(1-x_{\mathrm{Si}}^{s}\right)}
$$

The main component in the gas phase is silicon vapor and the amount of phosphorus is in the parts per million level, so the collisions between molecular silicon and phosphorus can be ignored. Then, the diffusion coefficient of silicon vapor is ${ }^{[21,22]}$

$$
D_{\mathrm{Si}(\mathrm{g})}=\frac{1}{3} \bar{v} \lambda_{\mathrm{Si}}=\frac{2}{3}\left(\frac{\mathrm{k}_{\mathrm{B}}^{3}}{\pi^{3} m_{\mathrm{Si}}}\right)^{1 / 2} \cdot \frac{T^{3 / 2}}{p \sigma_{\mathrm{Si}}^{2}}
$$

The evaporation of silicon proceeds at a constant rate when the effects of impurities are ignored. Thus, the accumulated evaporation of silicon as a function of time is

$$
J_{\mathrm{Si}}=j_{\mathrm{Si}}\left(t-t_{0}\right) M_{\mathrm{Si}}=A M_{\mathrm{Si}} \frac{k_{\mathrm{Si}}}{R T} p_{\mathrm{Si}}^{e}\left(t-t_{0}\right)(k g)
$$

\section{B. Kinetics of Phosphorus Evaporation}

The gas species of phosphorus evaporating from molten silicon is taken to be gas species $P$ and $P_{2}$. They follow first- and second-order kinetics, respectively:

$$
\begin{gathered}
\frac{d[\text { wt pct } P]_{1}}{d t}=-\frac{A}{V} k_{P}[\text { wt pct } P] \\
\frac{d[\text { wt pct } P]_{2}}{d t}=-\frac{A}{V} k_{P_{2}}[\text { wt pct } P]^{2}
\end{gathered}
$$

Then,

$$
\frac{d[\text { wt pct } P]}{d t}=-\frac{A}{V}\left(k_{P}[\text { wt pct } P]+k_{P_{2}}[\text { wt pct } P]^{2}\right)
$$

Here, $k_{P}$ and $k_{P_{2}}$ are the total mass transfer coefficients of gas species $P$ and $P_{2}$, respectively. Rearranging and integrating Eq. [19] yields

$$
[\text { wt pct } P]=\frac{k_{P}}{-k_{P_{2}}+\left(k_{P_{2}}+\frac{k_{P}}{[\text { wt pct } P]_{0}}\right) \cdot \exp \left(\frac{A}{V} k_{P}\left(t-t_{0}\right)\right)}
$$

\section{Evaporation of gas species $P$}

As is shown in Figure 4, silicon melt is in rapid movement caused by inductive stirring, so it is assumed that step 1 is not rate limiting for evaporation of gas species P. Step 5 is also assumed not to be rate limiting 
since condensation occurs on a very large area of cold surface and volatile components are pumped out. Therefore, steps 2 through 4 are considered to be rate limiting steps for phosphorus removal. These steps (Figure 4) will be discussed in the following.

\section{Step 2, transport across a "rigid" liquid boundary layer}

The liquid boundary layer (Figure 4) near the surface of the melt here is assumed to be moving without shear gradients under the influence of inductive stirring. Diffusion of an atom across such a boundary layer is much slower than turbulent transfer in the bulk phase, and the melt can be considered as a "rigid body." Because no external constraint is active on the surface of the melt, the rigid flow model of Machlin ${ }^{[23]}$ appears to be appropriate. The rate of decrease of the phosphorus concentration in silicon melt can be expressed by

$$
-\frac{d C}{d t}=2\left(C-C_{S}\right)\left(2 D_{P(l)} v / \pi r h^{2}\right)^{1 / 2}
$$

where $C$ is the concentration of phosphorus in the silicon melt and $C_{S}$ is the concentration at the melt surface (Figure 4). The mole flux of phosphorus across the boundary layer to the free melt surface becomes

$$
j_{P, \mathrm{St} .2}=-V \frac{d C}{d t}=k_{P, \mathrm{St} .2} A\left(C-C_{S}\right)(\text { moles } / \mathrm{s})
$$

with

$$
k_{P, \mathrm{St} .2}=\sqrt{8 D_{P(l)} v / \pi r}
$$

in which $v$ is the velocity of streamline flow. The velocity flow is created by the interaction between the induced currents and the magnetic field, which results in electromagnetic forces within the fluid, which, in turn, result in a vigorous stirring of the bath. The fluid velocities in induction melting furnaces were predicted theoretically by Tarapore and Evans ${ }^{[24,25]}$ and estimated as $0.1 \mathrm{~m} / \mathrm{s}$ by Machlin, ${ }^{[23]}$ corresponding to limiting values, which tend to maximize their quantity.

$D_{P(l)}$ is the phosphorus diffusion coefficient in molten silicon; it can be roughly estimated by the StokesEinstein equation modified by considering the effects of unequal mass of molecular silicon and phosphorus: ${ }^{[26]}$

$$
D_{P(l)}=\frac{\mathrm{k}_{\mathrm{B}} T}{4 \pi \eta R_{P}}\left(\frac{1}{2}+\frac{m_{P}}{2 m_{\mathrm{Si}}}\right)^{1 / 2}
$$

Here, $R_{P}$ is the atomic radius of phosphorus and $\eta$ is the viscosity of molten silicon: ${ }^{[27]}$

$$
\log \eta /(\mathrm{mPa} \cdot \mathrm{s})=-0.727+819 / T
$$

3. Step 3, vaporization from the free melt surface into the gas phase

The evaporation of $P$ gas from the free silicon melt surface, step 3 , for the special case of submitting to a perfect vacuum can be described by the Hertz-Langmuir-Knudsen equation: ${ }^{[28,29]}$

$$
j_{P, \mathrm{St} .3}=\frac{\alpha A p_{P}^{e}}{\sqrt{2 \pi R T M_{P}}} \quad(\text { moles } / \mathrm{s})
$$

From Eq. [4] in Table I, we set

$$
p_{P}^{*}=p_{\mathrm{atm}} \cdot \exp \left(-\Delta G_{2}^{o} / R T\right)
$$

and

$$
[\text { wt pct } P]=\frac{100 M_{P}}{\rho_{S i}} C_{S}
$$

so that

$$
j_{P, \mathrm{St} .3}=\frac{100 \alpha p_{P}^{*} f_{P}}{\rho_{\mathrm{Si}}} \sqrt{\frac{M_{P}}{2 \pi R T}} \cdot A \cdot C_{S} \quad(\text { moles } / \mathrm{s})
$$

We may write

$$
j_{P, \mathrm{St} .3}=k_{P, \mathrm{St} .3} A C_{S}
$$

with

$$
k_{P, \mathrm{St} .3}=\frac{100 \alpha p_{P}^{*} f_{P}}{\rho_{\mathrm{Si}}} \sqrt{\frac{M_{P}}{2 \pi R T}}
$$

Equation [26], which refers to the maximum rate of evaporation, is valid only when a perfect vacuum is attained, and all molecules evaporating are subsequently removed or condensed. When there is not a perfect vacuum above the silicon melt, the partial vapor pressure of phosphorus right above the melt, $p_{P}^{S}$, will not be equal to zero, and the driving force of phosphorus evaporating from the melt surface will be less than its maximum limiting value. Then, the evaporation of phosphorus from the free silicon melt surface is ${ }^{[17-19]}$

$$
j_{P, \mathrm{St} .3}=\frac{\alpha A\left(p_{P}^{e}-p_{P}^{s}\right)}{\sqrt{2 \pi R T M_{P}}}
$$

Here, $p_{P}^{s}$ is the partial pressure of phosphorus in the gas at the gas-liquid interface (Figure 4).

\section{Step 4, transport across the gas phase in the} chamber

The total flux of $P$ in step 4 should be equal to the diffusion flux plus the convective flux of $P .{ }^{[20]}$

$j_{P, \mathrm{St} .4}=-\frac{A D_{P(\mathrm{~g})} d p_{P}}{R T d z}+\frac{p_{P}}{p_{\mathrm{tot}}}\left(j_{P, \mathrm{St} .4}+j_{P_{2}, \mathrm{St} .4}+j_{\mathrm{Si}, \mathrm{St} .4}+j_{\mathrm{res}}\right)$

where $p_{P}$ is the partial pressure of gas species $P$ along axis $z$, and the diffusion of species $P$ in the gas phase can be considered as a quasi-steady state.

On the right-hand side of Eq. [33], compared with the flux of $\mathrm{Si}$, fluxes of species $P$ and $P_{2}$ can be ignored. The residual gas in the closed chamber can be seen as 
stagnant; then, rearranging and integrating Eq. [33], we obtain

$$
j_{\mathrm{Si}, \mathrm{St} .4}=-\frac{A D_{P(\mathrm{~g})} p_{t o t}}{R T \delta} \ln \left(\frac{p_{\mathrm{tot}} j_{P, \mathrm{St} .4}-p_{P}^{S} j_{\mathrm{Si}, \mathrm{St} .4}}{p_{\mathrm{tot}} j_{P, \mathrm{St} .4}-p_{P}^{c} j_{\mathrm{Si}, \mathrm{St} .4}}\right)
$$

Inserting Eq. [11] in Eq. [34] and setting $p_{P}^{c}, p_{\mathrm{Si}}^{c}$ as zero at the cold surface of the chamber, we have

$$
j_{P, \mathrm{St} .4}=j_{\mathrm{Si}, \mathrm{St} .4} \frac{p_{P}^{s}}{p_{\mathrm{tot}}}\left[\frac{1}{1-e^{\xi_{P}}}\right]
$$

or

$$
j_{P, \mathrm{St} .4}=-\frac{A D_{P(\mathrm{~g})}}{R T \delta} \cdot \frac{\xi_{P}}{1-e^{\xi_{P}}} \cdot p_{P}^{s}
$$

with

$$
\xi_{P}=\frac{D_{\mathrm{Si}(\mathrm{g})}}{D_{P(\mathrm{~g})}} \ln \left(1-x_{\mathrm{Si}}^{s}\right)
$$

where $D_{P(g)}$ is the molecular diffusion coefficient of phosphorus. Equation [35] indicates that the vaporizing flux of phosphorus depends on the flux of silicon based on the IVR model simplifying assumptions.

Since silicon vapor is the main gas species, molecular phosphorus collides with silicon rather than with phosphorus. Then, ${ }^{[21]}$

$$
\begin{aligned}
D_{P(\mathrm{~g})}= & \frac{2}{3}\left(\frac{\mathrm{k}_{\mathrm{B}}^{3}}{\pi^{3}}\right)^{1 / 2} \cdot\left(\frac{1}{2 m_{P}}+\frac{1}{2 m_{\mathrm{Si}}}\right)^{1 / 2} \\
& \cdot\left[T^{3 / 2} / p\left(\frac{\sigma_{P}+\sigma_{\mathrm{Si}}}{2}\right)^{2}\right]
\end{aligned}
$$

From Eq. [36], we have

$$
k_{P, \mathrm{St} .4}=\frac{D_{P(\mathrm{~g})}}{\delta} \cdot \frac{\xi_{P}}{e^{\xi_{P}}-1}
$$

\section{Total mass transfer coefficient of species $P$} from molten silicon

According to the quasi-steady-state approximation, $j_{P, \text { St.2 }}=j_{P, \text { St. } 3}=j_{P, \text { St.4 }}=j_{P}$. Inserting Eq. [36] in Eq. [32] to eliminate $p_{P}^{s}$ yields

$$
p_{P}^{e}=\frac{j_{P}}{A}\left(\frac{\sqrt{2 \pi R T M_{P}}}{\alpha}+\frac{R T}{k_{P, \mathrm{St} .4}}\right)
$$

From Eqs. [4], [27], [28], and [40], we have

$$
C_{S}=\left(\frac{1}{k_{P, \mathrm{St} .3}}+\frac{R T \rho_{\mathrm{Si}}}{100 k_{P, \mathrm{St} .4} p_{P}^{*} f_{P} M_{P}}\right) \frac{j_{P}}{A}
$$

Elimination of $C_{S}$ in Eq. [22] gives

$$
j_{P}=\frac{A C}{\frac{1}{k_{P, \mathrm{St} .2}}+\frac{1}{k_{P, \mathrm{St} .3}}+\frac{R T \rho_{S i}}{100 k_{P, \mathrm{St} .} p_{P}^{*} f_{P} M_{P}}}
$$

so that we have

$$
\frac{1}{k_{P}}=\frac{1}{k_{P, \mathrm{St} .2}}+\frac{1}{k_{P, \mathrm{St} .3}}+\frac{1}{k_{P, \mathrm{St} .4}^{\prime}}
$$

Table II. Mass Transfer Properties of Gas Species $\boldsymbol{P}_{2}$ from Silicon Liquid

$$
\begin{aligned}
& p_{P_{2}}^{*}=p_{\text {atm }} \cdot\left[\exp \left(-\Delta G_{1}^{\mathrm{o}} / R T\right)\right]^{2} \\
& p_{P_{2}}=p_{P_{2}}^{*} \cdot\left(f_{P} \cdot[\text { wt pct } P]\right)^{2} \\
& \frac{1}{k_{P_{2}}}=\frac{1}{k_{P_{2}, \mathrm{St} .2}}+\frac{1}{k_{P_{2}, \mathrm{St} .3}}+\frac{1}{k_{P_{2}, \mathrm{St} .4}^{\prime}} \\
& k_{P_{2}, \mathrm{St} .2}=\sqrt{8 D_{P(l)} v / \pi r} \\
& k_{P_{2}, \mathrm{St} .3}=\frac{100 \alpha p_{P_{2}}^{*} f_{P}^{2}}{\rho_{\mathrm{Si}}} \sqrt{\frac{M_{P_{2}}}{2 \pi R T}} \\
& k_{P_{2}, \mathrm{St} .4}=\frac{D_{P_{2}(\mathrm{~g})}}{\delta} \cdot \frac{\xi_{P_{2}}}{e^{\xi} P_{2}-1} \\
& \xi_{P_{2}}=\frac{D_{\mathrm{Si}(g)}}{D_{P_{2}(g)}} \ln \left(1-x_{\mathrm{Si}}^{s}\right) \\
& k_{P_{2}, \text { St.4 }}^{\prime}=\frac{100 p_{P_{2}}^{*} f_{P}^{2} M_{P_{2}}}{R T \rho_{\mathrm{Si}_{2}}} k_{P_{2}, \text { St.4 }}
\end{aligned}
$$

with

$$
k_{P, \mathrm{St} .4}^{\prime}=\frac{100 p_{P}^{*} f_{P} M_{P}}{R T \rho_{\mathrm{Si}}} k_{P, \mathrm{St} .4}
$$

\section{Evaporation of gas species $P_{2}$}

Formation of diatomic species at the gas-liquid interface is taken to be rapid at high phosphorus concentration. The mass transfer coefficients at each step of gas species $P_{2}$ can be obtained similarly to species $P$, as listed in Table II.

\section{CALCULATION RESULTS AND DISCUSSION}

\section{A. Vapor Pressure of Silicon at the Melt Surface}

The vapor pressure of silicon at the melt surface is a key factor for phosphorus evaporation, as evident from the flux of phosphorus shown in Eq. [35]. We take $j_{\mathrm{Si}, \mathrm{St} .3}=j_{\mathrm{Si}, \mathrm{St} .4}$, and combine Eqs. [8] and [11] to yield

$$
p_{\mathrm{Si}}^{s}=p_{\mathrm{Si}}^{e}+\frac{A D_{\mathrm{Si}(\mathrm{g})}}{R T \delta} \cdot \frac{\ln \left(1-x_{\mathrm{Si}}^{s}\right)}{x_{\mathrm{Si}}^{s}} \cdot p_{\mathrm{Si}}^{s} \cdot \frac{\sqrt{2 \pi R T M_{\mathrm{Si}}}}{\alpha A}
$$

or

$$
x_{\mathrm{Si}}^{s}=\frac{p_{\mathrm{Si}}^{e}}{p_{\mathrm{tot}}}+\frac{D_{\mathrm{Si}(\mathrm{g})}}{\alpha \delta} \cdot \sqrt{\frac{2 \pi M_{\mathrm{Si}}}{R T}} \cdot \ln \left(1-x_{\mathrm{Si}}^{s}\right)
$$

Equation [54] shows that the surface molar fraction of silicon vapor depends on chamber pressure and temperature. If we consider the evaporation coefficient $\alpha$ as unity for the silicon melt, then the vapor pressure of silicon at the melt surface can be calculated from Eq. [12]. The relation of $p_{\mathrm{Si}}^{s}$ to $p_{\mathrm{Si}}^{e}$ is plotted in Figure 5 as a function of chamber pressure at temperature $1873 \mathrm{~K}$ $\left(1600{ }^{\circ} \mathrm{C}\right)$.

As shown in Figure 5, the driving force of evaporation depends on the vertical distance from curve $p_{\mathrm{Si}}^{s}$ to line $p_{\mathrm{Si}}^{e}$, as is $\left(p_{\mathrm{Si}}^{e}-p_{\mathrm{Si}}^{s}\right)$. The influence of chamber pressure on the vapor pressure at the melt surface can be divided into three different regimes. (1) When the chamber pressure is much smaller than the equilibrium 
vapor pressure of silicon, which is $p<<p_{\mathrm{Si}}^{e}$, the pressure of silicon vapor at the surface increases linearly with the chamber pressure. The evaporation driving force is high. (2) When $p$ is close to $p_{\mathrm{Si}}^{e}$, the slope of $p_{\mathrm{Si}}^{s}$ decreases with increasing chamber pressure. Evaporation still occurs even at pressures higher than $3 \mathrm{~Pa}$, since there remains a pressure difference at the gas-liquid interface. When the chamber pressure is higher than $3 \mathrm{~Pa}, p_{\mathrm{Si}}^{s}$ will approach $p_{\mathrm{Si}}^{e}$. (3) When $p \gg p_{\mathrm{Si}}^{e}$, there is no driving force any more.

\section{B. Effect of Chamber Pressure}

The crucible inner diameter is taken as $0.2 \mathrm{~m}$, initial silicon mass $5 \mathrm{~kg}$, original phosphorus concentration $15 \mathrm{ppmw}$, and melting time $3.6 \mathrm{ks}$. The mass transfer coefficients of gas $P$ and $P_{2}$ are plotted as a function of chamber pressure and are shown in Figures 6(a) and (b),

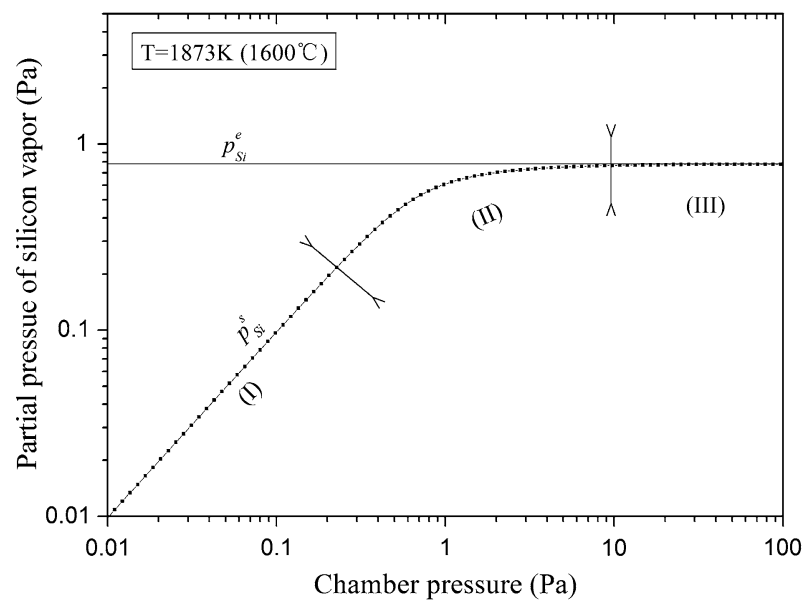

Fig. 5-Plots of equilibrium partial pressure $\left(p_{\mathrm{Si}}^{e}\right)$ and vapor partial pressure of silicon vapor at the melt surface $\left(p_{\mathrm{Si}}^{s}\right)$ as a function of chamber pressure. respectively. Phosphorus concentration and silicon yield are plotted in Figure 7.

As is shown in Figure 6(a), when chamber pressure is less than $0.471 \mathrm{~Pa}$, free evaporation of gas species $P$ becomes the mass transfer limiting step. The total mass transfer coefficient of gas species $P$ will be gradually independent of vacuum pressure lower than $0.1 \mathrm{~Pa}$ at temperature $1873 \mathrm{~K}\left(1600{ }^{\circ} \mathrm{C}\right)$. Transport of species $P$ in the gas phase (step 4) will gradually become the controlling step at chamber pressure greater than $0.471 \mathrm{~Pa}$. Similar but more obvious trends are shown in Figure 6(b) for gas species $P_{2}$; the mass transfer coefficient curve of steps 2 and 4 will cross at pressure $1.2 \mathrm{~Pa}$, transferring the mass transfer limitation from step 2 to step 4.

Figure 7 shows that, when the refining process is carried out at $1873 \mathrm{~K}\left(1600^{\circ} \mathrm{C}\right)$ for $3.6 \mathrm{ks}$, both phosphorus and silicon will evaporate slowly at pressures higher than $10 \mathrm{~Pa}$. Evaporation will speed up on decreasing the chamber pressure, and it will be

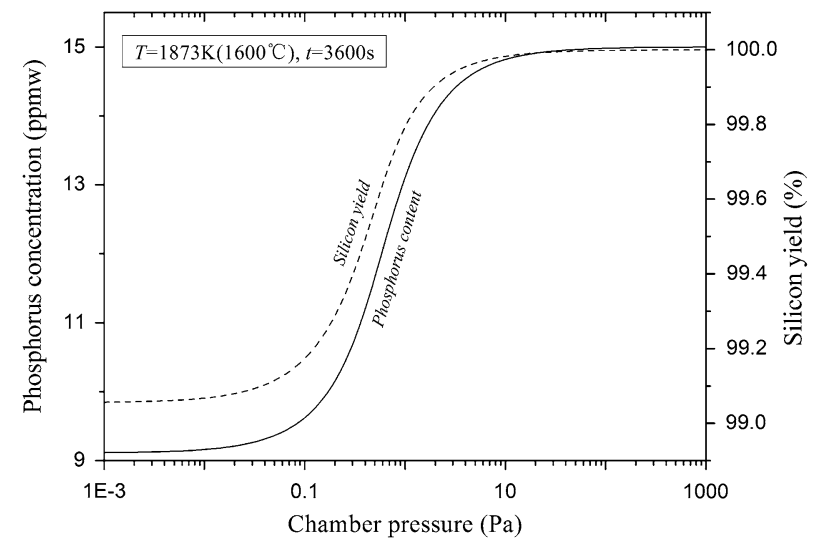

Fig. 7-Phosphorus removal and silicon yield as a function of chamber pressure.

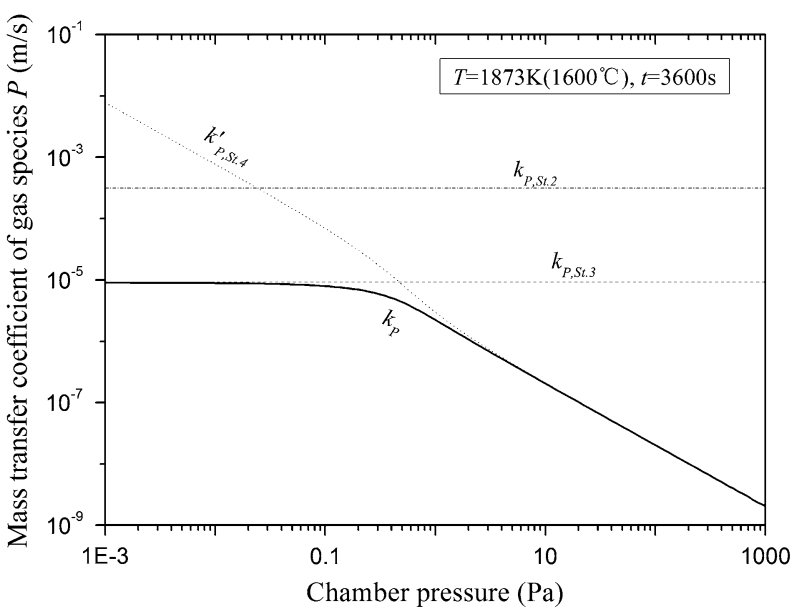

(a)

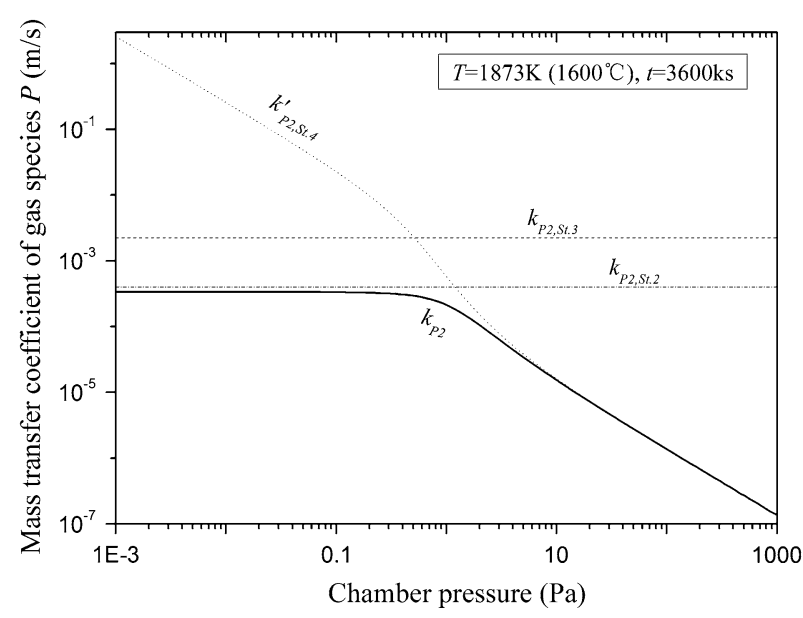

(b)

Fig. 6-Plots of mass transfer coefficients as a function of chamber pressure: (a) gas species $P$ and (b) gas species $P_{2}$. 
independent of the chamber pressure at pressures lower than $0.1 \mathrm{~Pa}$.

The total mass transfer coefficient of species $P_{2}$ is always one order greater than that of $P$ when initial phosphorus content is 15 ppmw; however, the partial pressure of species $P$ is more than two orders greater than that of species $P_{2}$ (Figure 2). So, species $P$ will limit the evaporation of phosphorus at low phosphorus concentration.

\section{Effect of Temperature}

The mass transfer coefficients of species $P$ and $P_{2}$ are plotted as a function of temperature and are shown in Figures 8(a) and (b), respectively.

As shown in Figures 8(a) and (b), the mass transfer coefficients of species $P$ and $P_{2}$ at steps 3 and 4 increase with increasing temperatures. In Figure 8(a), the cross point between mass transfer coefficients of steps 2 and 3 is at $2203 \mathrm{~K}\left(1930{ }^{\circ} \mathrm{C}\right)$; free evaporation will become the rate limiting step for the mass transfer of species $P$ at temperature below $2203 \mathrm{~K}\left(1930{ }^{\circ} \mathrm{C}\right)$. In Figure 8(b), the mass transport through the liquid boundary layer (step 2) will limit the evaporation of species $P_{2}$ at all temperatures when the chamber pressure is $0.1 \mathrm{~Pa}$.

There is a knee point at step 4 for both species $P$ and $P_{2}$ at a temperature of $1933 \mathrm{~K}\left(1660{ }^{\circ} \mathrm{C}\right)$, which can be explained by Figure 9.

As is shown in Figure 9, at a chamber pressure of $0.1 \mathrm{~Pa}$ and temperature of less than $1933 \mathrm{~K}\left(1660^{\circ} \mathrm{C}\right)$, the partial vapor pressure of silicon $\left(p_{\mathrm{Si}}^{s}\right)$ in the gas phase increases with the increase of temperature, while it goes to a constant of $0.1 \mathrm{~Pa}$ after $1933 \mathrm{~K}\left(1660{ }^{\circ} \mathrm{C}\right)$ no matter how high the equilibrium pressure of silicon $\left(p_{\mathrm{Si}}^{e}\right)$ achieved, since the partial vapor pressure can never exceed the chamber pressure. According to Eqs. [11] and [35], the mass transfer coefficients of phosphorus and silicon in step 4 are linear to $p_{\mathrm{Si}}^{s}$; as a result, the knee point exists at a temperature of $1933 \mathrm{~K}\left(1660^{\circ} \mathrm{C}\right)$.

\section{Effect of Original Phosphorus Concentration}

The original phosphorus concentrations are taken as 15, 50, and $150 \mathrm{ppmw}$, respectively. The phosphorus concentration and silicon yield are plotted as a function of temperature and are shown in Figure 10.

As is shown in Figure 10, phosphorus removal will be nearly independent of the original concentration at temperatures above $2103 \mathrm{~K}\left(1830^{\circ} \mathrm{C}\right)$, pressure of $0.1 \mathrm{~Pa}$, and holding time of $3.6 \mathrm{ks}$. This is because phosphorus evaporates as species $P_{2}$ at high phosphorus concentration and as species $P$ at low phosphorus concentration. The silicon yield does not vary with the phosphorus concentration.

At $2103 \mathrm{~K}\left(1830{ }^{\circ} \mathrm{C}\right)$ and $0.1 \mathrm{~Pa}$, phosphorus concentrations after $3.6 \mathrm{ks}$ are $0.1,0.17$, and 0.22 , corre-

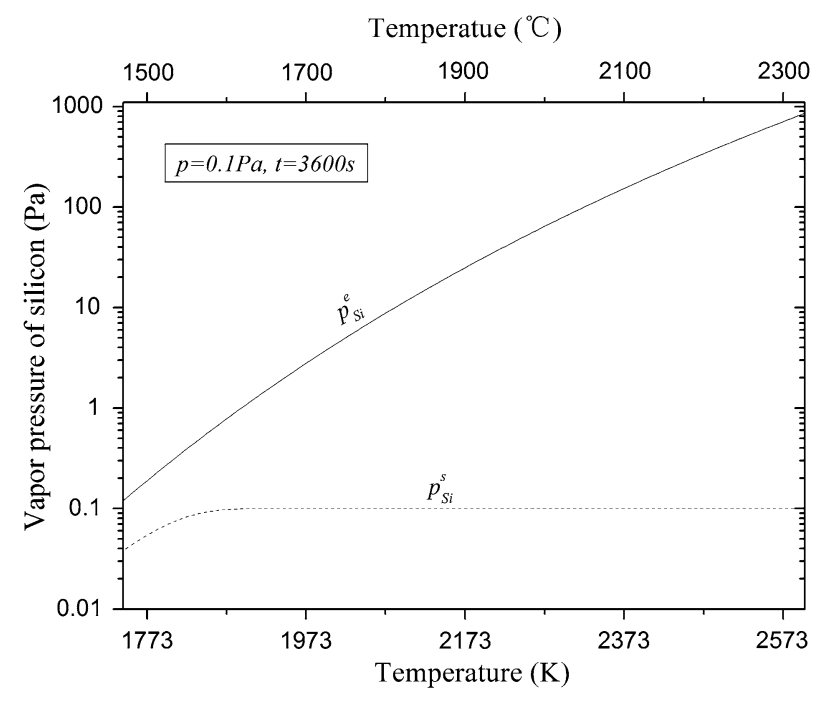

Fig. 9-Plots of equilibrium partial pressure $\left(p_{\mathrm{Si}}^{e}\right)$ and vapor partial pressure of silicon vapor at the melt surface $\left(p_{\mathrm{Si}}^{s}\right)$ as a function of temperature.



(a)

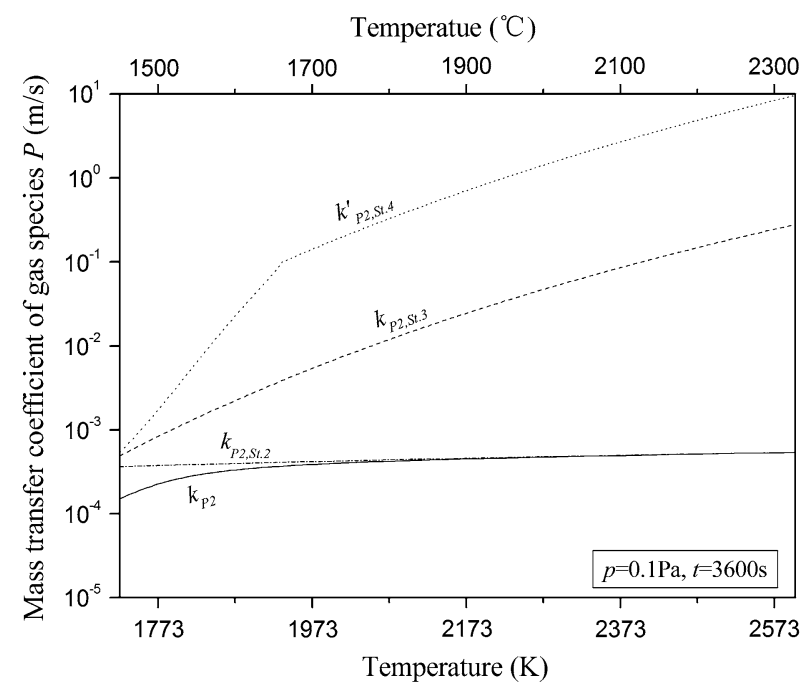

(b)

Fig. 8-Plots of mass transfer coefficients as a function of temperature: $(a)$ gas species $P$ and $(b)$ gas species $P_{2}$. 
sponding to original phosphorus contents of 15,50 , and 150 ppmw, respectively. The silicon yield is about 87 pet.

\section{E. Effects of Geometry of Silicon Melt}

The effect of geometry on phosphorus removal is usually given in terms of a ratio $A / V$. In this calculation, we assume that a cylindrical crucible is used. The effects of geometry on the mass transfer coefficients of species $P$ and $P_{2}$ are plotted as a function of diameter height ratio $(d / h)$ of silicon melt and are shown in Figures 11(a) and (b), respectively. Phosphorus concentration and silicon yield are plotted in Figure 12.

As shown in Figures 11(a) and (b), the geometry $(d / h)$ of silicon melt has hardly any effect on mass transfer coefficients of steps 3 and 4, and only a little on step 2 .

In Figure 12, the original phosphorus concentration is $15 \mathrm{ppmw}$, and the conditions are temperature of $1873 \mathrm{~K}$, pressure of $0.01 \mathrm{~Pa}$, and holding time of

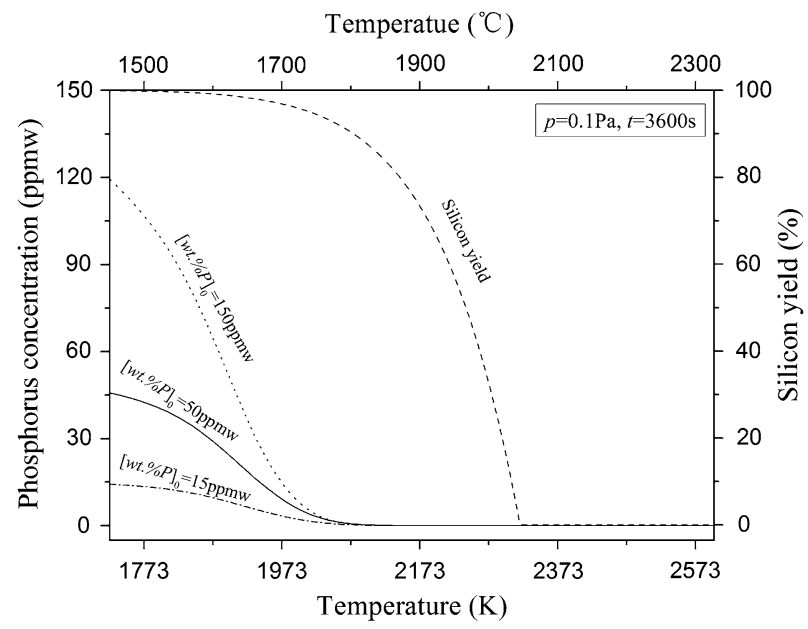

Fig. 10-Plots of phosphorus content and silicon yield as a function of temperature with initial phosphorus concentration of 15,50 , and 150 ppmw, respectively.

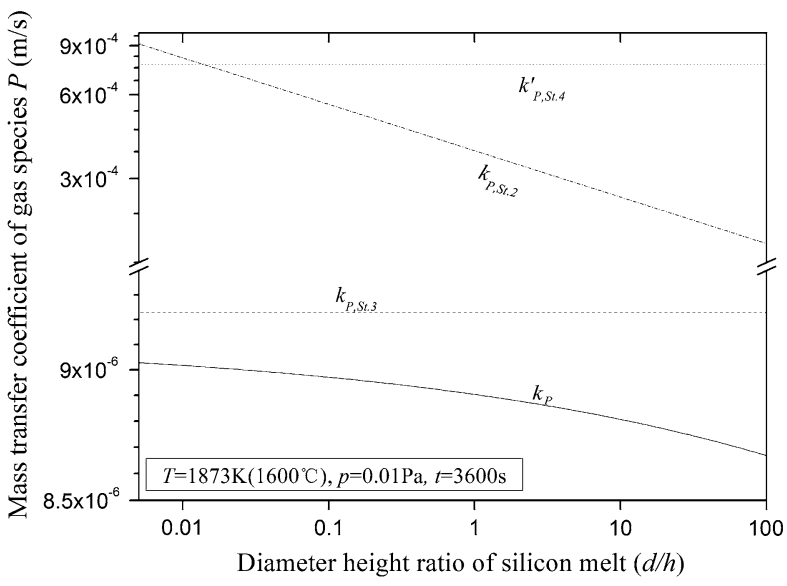

(a)
3.6 ks. Phosphorus removal obviously increases with increasing diameter-to-height ratio $(d / h)$ from 1 to 40 . Silicon yield goes down sharply when $d / h$ exceeds 10 . About 4 ppmw phosphorus is removed with a silicon yield of 99 pct when $d / h$ is equal to 1 . About $8 \mathrm{ppmw}$ phosphorus is removed with silicon yield of 98 pet when $d / h$ is 10 .

\section{F. Phosphorus Removal for Various Conditions}

Phosphorus concentration for various pressures and temperatures and silicon yield for the case of $2023 \mathrm{~K}$ $\left(1750{ }^{\circ} \mathrm{C}\right), 0.01 \mathrm{~Pa}$ are plotted as a function of holding time in Figure 13

As is shown in Figure 13, the curves can be presented in two groups: one is at a temperature of $1923 \mathrm{~K}$ $\left(1650{ }^{\circ} \mathrm{C}\right)$ with various pressures of $0.01,0.1,1$, and $10 \mathrm{~Pa}$, and the other is at a pressure of $0.01 \mathrm{~Pa}$ with various temperatures of $1723 \mathrm{~K}\left(1450{ }^{\circ} \mathrm{C}\right), 1823 \mathrm{~K}$ $\left(1550{ }^{\circ} \mathrm{C}\right), 1923 \mathrm{~K}\left(1650{ }^{\circ} \mathrm{C}\right)$, and $2023 \mathrm{~K}\left(1750^{\circ} \mathrm{C}\right)$.

Phosphorus concentration at $1923 \mathrm{~K}\left(1650^{\circ} \mathrm{C}\right)$ and $1 \mathrm{~Pa}$ is lower than that at $1823 \mathrm{~K}\left(1550{ }^{\circ} \mathrm{C}\right)$ and $0.01 \mathrm{~Pa}$.

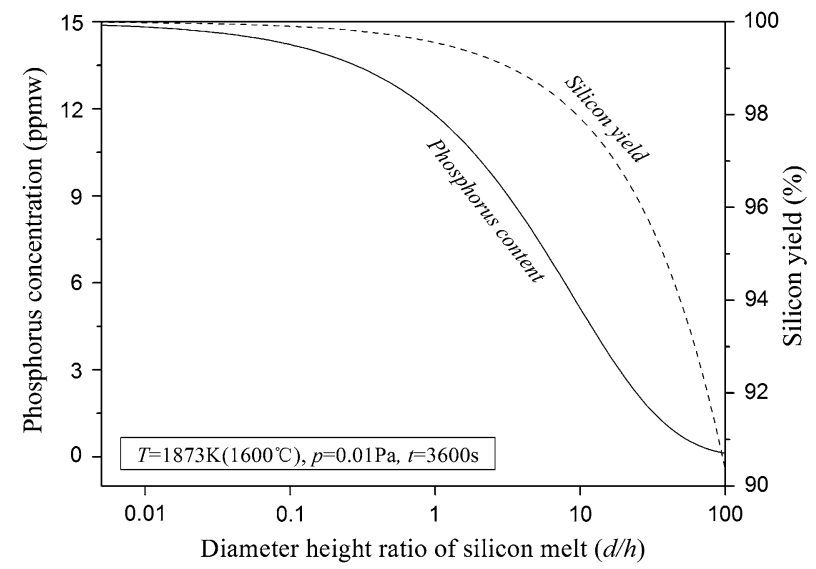

Fig. 12-Plots of phosphorus concentration and silicon yield as a function of diameter height ratio $(d / h)$ of silicon melt

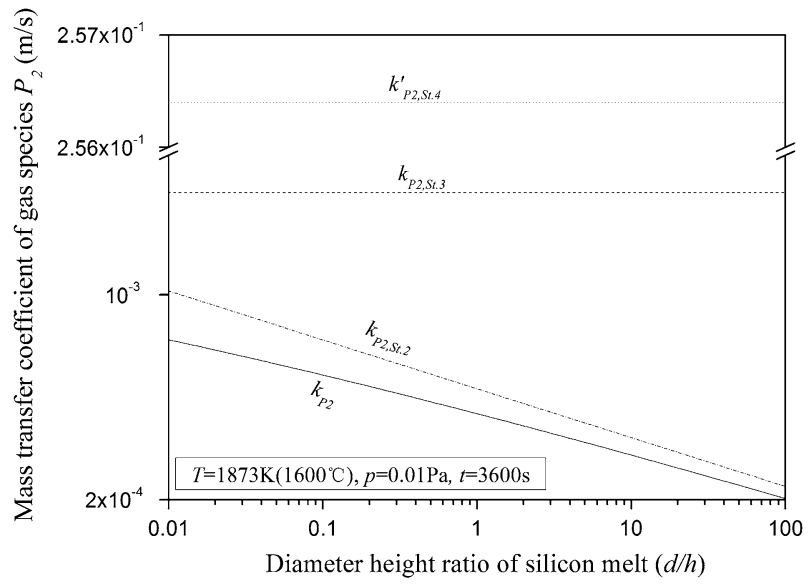

(b)

Fig. 11-Plots of mass transfer coefficients as a function of diameter height ratio $(d / h)$ of silicon melt: (a) gas species $P$ and (b) gas species $P_{2}$. 
This finding shows that temperature is more important than pressure. At low chamber pressure, phosphorus removal is nearly independent of pressure. For example, the phosphorus concentration curve for $1923 \mathrm{~K}$ $\left(1650^{\circ} \mathrm{C}\right.$ ) and $0.1 \mathrm{~Pa}$ nearly overlaps with the curve for $1923 \mathrm{~K}\left(1650^{\circ} \mathrm{C}\right)$ and $0.01 \mathrm{~Pa}$.

The curve at $2023 \mathrm{~K}\left(1750{ }^{\circ} \mathrm{C}\right), 0.01 \mathrm{~Pa}$ shows that it should take more than $7 \times 10^{3} \mathrm{~s}$ to decrease phosphorus from 15 ppmw to less than 0.1 ppmw. Also, 11 pct silicon is lost.

\section{EXPERIMENTAL DATA AND DISCUSSION}

Experiments both in small scale ${ }^{[4]}$ and pilot scale were performed in the present study. In the small scale experiments, $0.1 \mathrm{~kg}$ MG-Si (99.98 pct $\mathrm{Si}$ ) is added in a high-purity graphite ( $>99.998$ pct C) crucible with an inner diameter $0.05 \mathrm{~m}$, outer diameter $0.06 \mathrm{~m}$, and depth $0.12 \mathrm{~m}$. Melting is carried out under argon atmosphere of $80,000 \mathrm{~Pa}$. After complete melting, the chamber is evacuated to the specified pressure and temperature as fast as possible. The temperature is measured using a pyrometer with an error of $\pm 20 \mathrm{~K}$ $\left( \pm 20^{\circ} \mathrm{C}\right)$. Then the melt is held for a period of time as $15,30,45$, and 60 minutes, respectively. At the end of

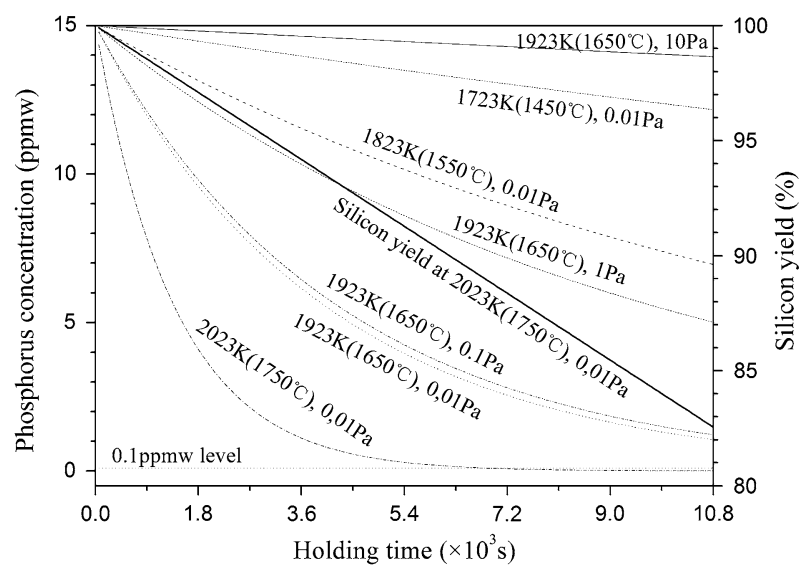

Fig. 13-Plots of phosphorus concentration for various pressures and temperatures and silicon yield as a function of holding time. the experiment, the melt is cast into a graphite mold, sampled, and analyzed by inductively coupled plasma atomic emission spectroscopy. The experimental parameters are listed in Table III.

In the pilot scale experiments, MG-Si powder after acid leaching is employed as a raw material in order to reduce the effect of other volatile elements. The main impurity elements are listed in Table IV.

An induction melting and casting unit was used. The crucible-coil assembly is positioned approximately at the center of a water-cooled vacuum chamber of $1-\mathrm{m}$ diameter and 1-m depth. Five to ten kilograms of silicon is melted by induction heating in a high-purity graphite ( 99.998 pct C) crucible with an inner diameter $0.2 \mathrm{~m}$, outer diameter $0.25 \mathrm{~m}$, and depth $0.2 \mathrm{~m}$. In order to avoid the effects of phosphorus evaporation during the melting stage, silicon is melted under $80,000 \mathrm{~Pa}$ argon pressure. During the refining, the temperature is measured continuously with a two-color optical pyrometer. With continuous temperature measurement and manual control of the power input to the furnace, the temperature of the melt could be maintained constant within $\pm 10 \mathrm{~K}\left( \pm 10^{\circ} \mathrm{C}\right)$. The ingots are sawed and analyzed by inductively coupled plasma mass spectrometry. The calculation results using the IVR model are given in Table $\mathrm{V}$.

Experimental data both from small scale and pilot scale experiments are compared to the IVR model and plotted in Figure 14.

As shown in Figure 14, the numerical results using the IVR model for the Si- $P$ binary system agree well with the pilot scale experimental data. Deviations in the small scale experiments may be due to several possible reasons. The presence of other solutes, such as $\mathrm{Al}, \mathrm{Ca}$, $\mathrm{Fe}, \mathrm{B}$, etc., will affect the diffusivity and activity of phosphorus in molten silicon. The presence of volatile elements, such as $\mathrm{Al}, \mathrm{Ca}$, and $\mathrm{Fe}$, has effects on phosphorus vaporization and gas-phase transfer.

Table IV. Main Impurity Contents in MG-Si Used in the Present Experiments $\left(\times 10^{-4}\right.$ Percent $)$

\begin{tabular}{lccccc}
\hline $\mathrm{P}$ & $\mathrm{Al}$ & $\mathrm{Ca}$ & $\mathrm{Fe}$ & $\mathrm{Ti}$ & $\mathrm{B}$ \\
\hline 11 to 19 & 8 to 13 & 2 to 3 & 5 to 7 & $<0.1$ & 6 to 8 \\
\hline
\end{tabular}

Table III. Experimental Parameters in Small Scale

\begin{tabular}{|c|c|c|c|c|c|c|c|}
\hline \multirow{2}{*}{$\begin{array}{l}\text { Experimental } \\
\text { Group } \\
\text { Number }\end{array}$} & \multirow{2}{*}{$\begin{array}{l}\text { Crucible Inner } \\
\text { Diameter }(\mathrm{m})\end{array}$} & \multirow[b]{2}{*}{ Mass (kg) } & \multirow{2}{*}{$\begin{array}{l}{[\mathrm{Wt} \text { Pct } P]_{0}} \\
\left.\times 10^{-4} \mathrm{Pct}\right)\end{array}$} & \multirow[b]{2}{*}{ Pressure (Pa) } & \multicolumn{2}{|c|}{ Temperature } & \multirow{2}{*}{$\begin{array}{c}\text { Holding } \\
\text { Time } \times 10^{3} \mathrm{~s}\end{array}$} \\
\hline & & & & & $\mathrm{K}$ & ${ }^{\circ} \mathrm{C}$ & \\
\hline 1 & 0.025 & 0.1 & 33.91 & 0.034 to 0.042 & 1763 to 1793 & 1490 to 1520 & $0.9 / 1.8 / 2.7 / 3.6$ \\
\hline 2 & 0.025 & 0.1 & 33.91 & 0.18 to 0.3 & 1763 to 1793 & 1490 to 1520 & $0.9 / 1.8 / 2.7 / 3.6$ \\
\hline 3 & 0.025 & 0.1 & 33.91 & 1 & 1763 to 1793 & 1490 to 1520 & $0.9 / 1.8 / 2.7 / 3.6$ \\
\hline 4 & 0.025 & 0.1 & 33.91 & 10 & 1763 to 1793 & 1490 to 1520 & $0.9 / 1.8 / 2.7 / 3.6$ \\
\hline 5 & 0.025 & 0.1 & 33.91 & 100 & 1763 to 1793 & 1490 to 1520 & $0.9 / 1.8 / 2.7 / 3.6$ \\
\hline 6 & 0.025 & 0.1 & 33.91 & 1000 & 1763 to 1793 & 1490 to 1520 & $0.9 / 1.8 / 2.7 / 3.6$ \\
\hline 7 & 0.025 & 0.1 & 33.91 & 10000 & 1763 to 1793 & 1490 to 1520 & $0.9 / 1.8 / 2.7 / 3.6$ \\
\hline 8 & 0.025 & 0.1 & 33.91 & 0.11 to 6.2 & 1823 to 1883 & 1550 to 1610 & $1.8 / 2.7 / 3.6$ \\
\hline 9 & 0.025 & 0.1 & 33.91 & 8.9 to 11 & 1793 to 1923 & 1520 to 1650 & $1.8 / 2.7 / 3.6$ \\
\hline 10 & 0.025 & 0.1 & 33.91 & 20 to 22 & 1793 to 1903 & 1520 to 1630 & $1.8 / 2.7 / 3.6$ \\
\hline 11 & 0.025 & 0.1 & 33.91 & 90 to 110 & 1843 to 1923 & 1570 to 1650 & $1.8 / 2.7 / 3.6$ \\
\hline
\end{tabular}


Table V. Calculation Results Using IVR Model for Various Conditions

\begin{tabular}{|c|c|c|c|c|c|c|c|c|}
\hline \multirow{2}{*}{$\begin{array}{l}\text { Sample } \\
\text { Number }\end{array}$} & \multirow{2}{*}{$\begin{array}{c}\text { Silicon } \\
\text { Mass }(\mathrm{kg})\end{array}$} & \multicolumn{2}{|c|}{ Temperature } & \multirow{2}{*}{$\begin{array}{c}\text { Vacuum } \\
\text { Pressure }(\mathrm{Pa})\end{array}$} & \multirow{2}{*}{$\begin{array}{l}\text { Holding Time } \\
\quad \times 10^{3} \mathrm{~s}\end{array}$} & \multirow{2}{*}{$\begin{array}{l}{[\mathrm{Wt} \text { Pct } P]_{0}} \\
\times 10^{-4} \mathrm{Pct}\end{array}$} & \multirow{2}{*}{$\begin{array}{l}{[\mathrm{Wt} \text { Pct } P]_{t}} \\
\times 10^{-4} \mathrm{Pct}\end{array}$} & \multirow{2}{*}{$\begin{array}{l}\text { Silicon } \\
\text { Yield Pct }\end{array}$} \\
\hline & & $\mathrm{K}$ & ${ }^{\circ} \mathrm{C}$ & & & & & \\
\hline 1 & 5 & 1873 & 1600 & 0.032 to 0.07 & 7.2 & 24 & 9.16 & 98.2 \\
\hline 2 & 5 & 1873 & 1600 & 0.022 to 0.14 & 7.2 & 13 & 5.56 & 98.3 \\
\hline 3 & 5 & 1923 & 1650 & 0.04 to 0.059 & 1.8 & 16 & 10.29 & 99.14 \\
\hline 4 & 5 & 1923 & 1650 & 0.024 to 0.073 & 3.6 & 15 & 6.26 & 98.27 \\
\hline 5 & 5 & 1923 & 1650 & 0.031 to 0.091 & 5.4 & 12 & 3.31 & 97.42 \\
\hline 6 & 5 & 1923 & 1650 & 0.034 to 0.13 & 7.2 & 12 & 2.23 & 96.6 \\
\hline 7 & 5 & 1923 & 1650 & 0.018 to 0.046 & 7.2 & 17 & 2.93 & 96.5 \\
\hline 8 & 7.5 & 1923 & 1650 & 0.03 to 0.14 & 7.2 & 19 & 6.03 & 97.25 \\
\hline 9 & 5 & 1973 & 1700 & 0.02 to 0.069 & 3.6 & 7 & 1.55 & 96.8 \\
\hline 10 & 5 & 1973 & 1700 & 0.019 to 0.078 & 7.2 & 13 & 0.61 & 93.6 \\
\hline 11 & 5 & 1973 & 1700 & 0.044 to 0.25 & 7.2 & 24 & 1.24 & 93.97 \\
\hline 12 & 5 & 1973 & 1700 & 0.017 to 0.11 & 7.2 & 7 & 0.34 & 93.64 \\
\hline 13 & 5 & 1973 & 1700 & 0.02 to 0.13 & 10.8 & 11 & 0.11 & 90.5 \\
\hline 14 & 10 & 1973 & 1700 & 0.022 to 0.16 & 7.2 & 7 & 1.61 & 96.88 \\
\hline
\end{tabular}

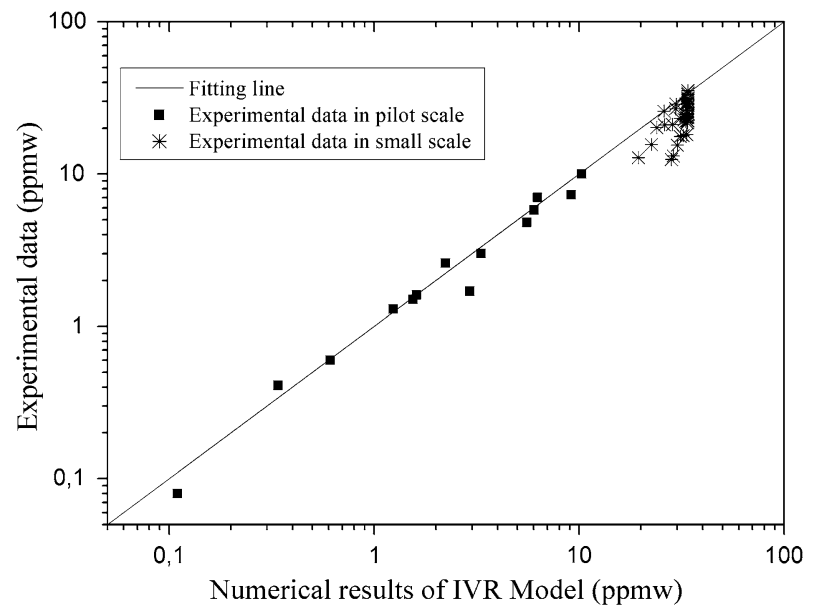

Fig. 14 Comparison of experimental data to calculated results from IVR model.

The induction stirring created by electromagnetic field will form a surface with mushroom face, ${ }^{[24,25]}$ which will increase the surface area of evaporation, especially in small scale experiments.

\section{CONCLUSIONS}

A kinetic model of phosphorus removal from silicon by IVR is presented in this article. We assume that phosphorus evaporates from silicon melt as gas species $P$ and $P_{2}$. Mass transfer in the liquid boundary layer (step 2), free evaporation in the gas-liquid interface (step 3 ), and diffusion in the gas (step 4) are considered to be the possible rate limiting steps.

Temperature, pressure, geometry of melt, holding time, and original phosphorus concentration were taken into account in this model, and their influence on mass transfer coefficients, phosphorus removal, and silicon yield is discussed.

Pressure is an important factor affecting evaporation. Evaporation can be divided into three regimes with increasing chamber pressure. In the first regime, when the chamber pressure $(p)$ is much smaller than the equilibrium partial pressure of silicon vapor $\left(p_{\mathrm{Si}}^{e}\right)$, which is $p<<p_{\mathrm{Si}}^{e}$, the pressure of silicon vapor at the melt surface increases linearly with the chamber pressure and the evaporation driving force is high; in the second regime, when $p$ is close to $p_{\mathrm{Si}}^{e}$, the driving force will decrease and approach zero with increasing chamber pressure; and in the third regime, as $p>>p_{\mathrm{Si}}^{e}$, no more evaporation will occur since there is no driving force at the gas-liquid interface.

Temperature is another key factor. Mass-transfer coefficients of species $P$ and $P_{2}$ at steps 3 and 4 increase with increasing temperatures. Free evaporation limits the mass transfer rate of species $P$ at a temperature lower than $2203 \mathrm{~K}\left(1930{ }^{\circ} \mathrm{C}\right)$ and pressure of $0.1 \mathrm{~Pa}$.

The original phosphorus concentration will determine which gas species of phosphorus evaporates from the silicon melt. Species $P$ dominates in the gas at low phosphorus concentration. At high phosphorus concentration, phosphorus evaporates mainly as species $P_{2}$ and is limited by step 2 at all temperatures when the chamber pressure is $0.1 \mathrm{~Pa}$. At a high temperature above $2103 \mathrm{~K}$ $\left(1830^{\circ} \mathrm{C}\right)$ and a low pressure of $0.1 \mathrm{~Pa}$, the final phosphorus concentration does not significantly depend on the original phosphorus concentration.

The geometry of silicon melt has hardly any effect on the mass transfer coefficients of steps 3 and 4 , and only a little on step 2. Phosphorus removal obviously increases with increasing the diameter to height ratio $(d / h)$ from 1 to 40 . Silicon yield goes down sharply when $d / h$ exceeds 10 .

In conclusion, the factors affecting phosphorus removal in decreasing order are temperature, chamber pressure, geometry of silicon melt, holding time, and original phosphorus concentration. The best conditions for phosphorus removal are high temperature, relatively low pressure, and large surface area. High phosphorus removal will be accompanied by high silicon loss. The IVR model agrees well with the experimental data in the present study. 


\section{ACKNOWLEDGMENTS}

The authors gratefully acknowledge the financial support from the Natural Science Foundation of Fujian, Province of China (Grant No. 2007J0012); the Key Technological Program of Fujian, Province of China (Grant No. 2007HZ0005-2); and the BASIC project of NTNU supported by the Norwegian Research Council. We wish to express our sincere thanks to Drs. Kai Tang and Eivind J. Øvrelid, SINTEF (Norway), for their review and discussion of this article. We also appreciate the assistance of $\mathrm{Mr}$. Yalong $\mathrm{Li}$, Xiamen University (XMU) (Xiamen, China), in carrying out the experiments.

\section{OPEN ACCESS}

This article is distributed under the terms of the Creative Commons Attribution Noncommercial License which permits any noncommercial use, distribution, and reproduction in any medium, provided the original author(s) and source are credited.

\section{NOMENCLATURE}

$A$

C

$C_{s}$

$D_{\mathrm{i}(g)}$

$D_{\mathrm{i}(l)}$

$d$

$f_{\mathrm{i}}$

$\geq G_{n}^{\circ}$

$h$

$j_{\mathrm{i}}$

$j_{\mathrm{i}, \mathrm{St} . m}$

$j_{\text {res }}$

$J_{\mathrm{Si}}$

K

$\mathrm{k}_{\mathrm{B}}$

$k_{\mathrm{i}, \mathrm{St} . \mathrm{m}}$

$k_{\mathrm{i}}$

$k_{\mathrm{i}, \mathrm{St} .4}^{\prime}$

$M_{\mathrm{i}}$ surface area at the gas-liquid interface $\left[\mathrm{m}^{2}\right]$

phosphorus concentration in the bulk melt $\left[\mathrm{mol} / \mathrm{m}^{3}\right]$

phosphorus concentration at the melt surface $\left[\mathrm{mol} / \mathrm{m}^{3}\right]$

diffusion coefficient of $i$ in the gas phase (i $\left.=P, P_{2}, \mathrm{Si}\right)\left[\mathrm{m}^{2} / \mathrm{s}\right]$

diffusion coefficient of $i$ in the liquid (i $\left.=P, P_{2}, \mathrm{Si}\right)\left[\mathrm{m}^{2} / \mathrm{s}\right]$

inner diameter of crucible $[\mathrm{m}]$

Henry activity coefficient solute i related

to $1 \mathrm{wt}$ pct in an infinitely dilute solution $\left(\mathrm{i}=P, P_{2}\right)$

Gibbs free energy change of equilibrium

$[\mathrm{J} / \mathrm{mol}]$

height of melt $[\mathrm{m}]$

flux of $\mathrm{i}$ at equilibrium $\left(\mathrm{i}=P, P_{2}, \mathrm{Si}\right)$ $[\mathrm{mol} / \mathrm{s}]$

flux of i (i $\left.=P, P_{2}, \mathrm{Si}\right)$ at step $m(m=2$, $3,4)[\mathrm{mol} / \mathrm{s}]$

flux of the residual gas in the chamber $[\mathrm{mol} / \mathrm{s}]$

mass loss of silicon for a period of time

$[\mathrm{kg}]$

equilibrium constant

Boltzmann constant, $1.3806503 \times 10^{-23}$ $\mathrm{m}^{2} \mathrm{~kg} / \mathrm{s}^{2} \mathrm{~K}$

mass transfer coefficient of i (i $\left.=P, P_{2}, \mathrm{Si}\right)$ gas at step $m(m=2,3,4)[\mathrm{m} / \mathrm{s}]$

total mass transfer coefficient of $\mathrm{i}(\mathrm{i}=P$, $\left.P_{2}, \mathrm{Si}\right)[\mathrm{m} / \mathrm{s}]$

mass transfer coefficient of i $\left(\mathrm{i}=P, P_{2}\right)$ relative to step $4[\mathrm{~m} / \mathrm{s}]$

molecular mass of $\mathrm{i}\left(\mathrm{i}=P, P_{2}, \mathrm{Si}\right), 10^{-3}$ $\mathrm{kg} / \mathrm{mol}$
$\mathrm{R}$

$R_{P}$

\section{$t$}

$T$

$v$

$\bar{v}$

V

[wt pet i]

[wt pet $P]_{0}$

$x_{\mathrm{i}}$
$x_{\mathrm{Si}}^{S}$

$z$

\section{GREEK LETTERS}

$\alpha \quad$ surface evaporation coefficient, taken as unity

$\delta$ distance from the melt surface to the condensation surface $[\mathrm{m}]$

$\eta \quad$ viscosity of silicon, $10^{-3} \mathrm{~Pa} \mathrm{~s}$

$\rho_{\mathrm{Si}} \quad$ density of silicon melt, $2500 \mathrm{~kg} / \mathrm{m}^{3}$

$+\lambda_{\mathrm{i}}$ mean free path of molecule $\mathrm{i}$ in the gas phase (i $\left.=P, P_{2}, \mathrm{Si}\right)[\mathrm{m}]$

$\sigma_{\mathrm{i}} \quad$ diameter of molecule i $\left(\mathrm{i}=P, P_{2}, \mathrm{Si}\right)[\mathrm{m}]$

$\pi \quad \mathrm{Pi}=3.1415926$

$\varepsilon_{1}^{j} \quad$ activity interaction coefficient between $i$ and $j$

$\gamma_{\mathrm{Si}} \quad$ Raoultian activity coefficient of silicon

$\xi_{i} \quad$ diffusion effect factor of silicon vapor on gas species $\mathrm{i}\left(\mathrm{i}=\mathrm{P}, \mathrm{P}_{2}\right)$

\section{UNIT}

ppmw $10^{-4}$ mass percent 


\section{REFERENCES}

1. B.R. Bathey and M.C. Cretella: J. Mater. Sci., 1982, vol. 17, pp. 3077-96.

2. B.G. Gribov and K.V. Zinov'ev: Inorg. Mater., 2003, vol. 39, pp. 653-62.

3. J. Dietl: Solar Cells, 1983, vol. 10, pp. 145-54.

4. S. Zheng, J. Cai, C. Chen, and X. Luo: 3rd Int. Workshop on Science and Technology of Crystalline Si Solar Cells, Trondheim, Norway, Norwegian University of Science and Technology, Trondheim, Norway, 2009, CSSC-3, pp. 13-15.

5. M. Miyake, T. Hiramatsu, and M. Maeda: J. Jpn. Inst. Met., 2006, vol. 70, pp. 43-46.

6. N. Yuge, K. Hanazawa, K. Nishikawa, and H. Terashima: J. Jpn. Inst. Met., 1997, vol. 61, pp. 1086-93.

7. K. Suzuki, K. Sakaguchi, T. Nakagiri, and N. Sano: J. Jpn. Inst. Met., 1990, vol. 54, pp. 161-67.

8. J.C.S. Pires, J. Otubo, A.F.B. Braga, and P.R. Mei: J. Mater. Process. Technol., 2005, vol. 169, pp. 16-20.

9. T. Ikeda and M. Maeda: ISIJ Int., 1992, vol. 32, pp. 635-42.

10. T. Miki, K. Morita, and N. Sano: Metall. Mater. Trans. B, 1996, vol. 27B, pp. 937-41.

11. A.I. Zaitsev, N.E. Shelkova, and A.A. Kodentsov: J. Phase Equilib., 2000, vol. 21, pp. 528-33.

12. C. Mosselman, W.H.V. Vugt, and H. Vos: J. Chem. Eng. Data, 1982, vol. 27, pp. 246-51.

13. O. Kubaschewski, E. LL. Evans, and C.B. Alcock: Metallurgical Thermo-chemistry, 4th ed., Pergamon Press Ltd., Oxford, United Kingdom, 1979, pp. 408-20.

14. M.E. Schlesinger: Chem. Rev., 2002, vol. 102, pp. 4267-4301.
15. C. Wagner: Thermodynamics of Alloys, Addison-Wesley Press, Inc., Reading, MA, 1952, p. 51.

16. T. Shimpo, T. Yoshikawa, and K. Morita: Metall. Mater. Trans. $B$, 2004, vol. 35B, pp. 277-84.

17. F.D. Richardson: Physical Chemistry of Melts in Metallurgy, 1st ed., Academic Press, New York, NY, 1974, vol. 2, pp. 483-94.

18. E. Ozberk and R.I.L. Guthrie: Metall. Mater. Trans. B, 1986, vol. 17B, pp. 87-103.

19. S.T. Junder, R.W. Birkmire, and F.J. Doyle, III: AIChE J., 2005, vol. 51, pp. 878-94.

20. C.J. Geankoplis: Mass Transport Phenomena, Holt, Rinehart and Winston, Inc., New York, NY, 1972, pp. 40-45.

21. R.B. Bird, W.E. Stewart, and E.N. Lightfoot: Transport Phenomena, John Wiley \& Sons, New York, NY, 1960, pp. 508-10.

22. C.J. Geankoplis: Mass Transport Phenomena, Holt, Rinehart and Winston, Inc., New York, NY, 1972, pp. 23-25.

23. E.S. Machlin: Trans. TMS-AIME, 1960, vol. 218, pp. 314-26.

24. E. Tarapore and J. Evans: Metall. Trans. B, 1976, vol. 7B, pp. 343-51.

25. E. Tarapore and J. Evans: Metall. Trans. B, 1977, vol. 8B, pp. 179-84.

26. T. Abel Engh: Principles of Metal Refining, Oxford University Press, Oxford, United Kingdom, 1992, p. 116.

27. Y. Sato, Y. Kameda, T. Nagasawa, T. Sakamoto, S. Moriguchi, T. Yamamura, and Y. Waseda: J. Cryst. Growth, 2003, vol. 249, pp. 404-15.

28. A. Bronson and J. Chessa: J. Am. Ceram. Soc., 2008, vol. 91, pp. $1448-52$.

29. K. Ono and R. O. Suzuki: J. Mass Spectrum. Soc. Jpn., 1999, vol. 47 , pp. $38-41$. 